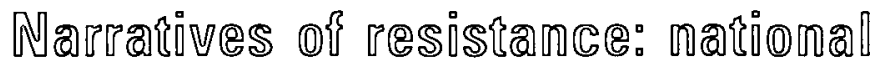 idencotity and ambivalence in the Turkish melodrama beinneen 1965 and 1975
}

\section{NEEIH ERDOGAN}

1 The large majority of the films cited in this essay were not released in English-speaking countries I am however adding my own English translation of the orignal tules to give an idea of their content
2 Nijat Ozon fuat Uzkmay (Istanbul TSD 1970) clied in Giovannı Scognamillo Türk Sinema Tanh 1896-1986 (Istanbul Metus 1987) p 28

\section{National cinema and an identity in crisis}

One of the first Turkısh feature films, Murebbiye/The Tutor (Ahmet Fehım, 1919) ${ }^{1}$ was banned by the allied forces which had occupied Istanbul just after World War I. It was adapted from Huseyın Rahmı Gurpinar's novel of the same title, published in 1898. Murebbive tells the story of a French woman who seduces the members of a snobbish family she works for. Apparently the text was meant to give a comical illustration of the upper classes' infatuation with French culture. But the film was released in the context of the occupation of Istanbul by the allied forces, and by then the focus was on the corrupt French tutor who, more or less, represented western woman Domestıc film cırcles read Murebblye as Turkısh cinema's 'silent resistance' to occupation. ${ }^{2}$ What is more interestıng is that the censor for the allied forces banned the film on the same grounds.

Woman as the site of production of meaning is one of the issues that I will discuss in this essay. For now, I would like to point out that the expression 'silent resistance' is somewhat problematic here To the Turkısh eye, the cinema was a western form of entertainment right from the start Sigmund Weınberg, a Polısh Jew of Romanıan nationality, launched the first regular public screenings in Istanbul in 
3 Nilgun Abisel gives a detailed account of how intellectuals debated the tension between foreign films and cultural identity in her work Turk Sinemast Uzerne Yazlar (Ankara Imge. 1994)

4 Yeșlçam is a street in Istanbul where film production companies gathered untul a decade ago it also denotes a specific system of production-distribution-exhibition that dominated the Turkish cınema between the late 1950 s and mid 1980s

5 Ikılem yanlış konunca Yenı Sinema nos 19/20 (June/July 1968) म 3
1896. These were Lumière shorts, L'arrivée d'un train en gare de la Ciotat (1895) among them Weinberg also made some documentanes and was reputed to be an 'expert' in conematography. Soon, companies such as Lumıère, Pathé, Gaumont and Ciné Théâtrale d'Orient began to distribute French, American, German and Danısh films. In the beginning, the audience of these films consısted mostly of the non-Muslım minorities who lived in Pera (now Beyoğlu), a district of Istanbul marked by a western life style D. Henri screened films in a pub named 'Sponeck'; Matalon, another Jew, in the 'Luksemburg Buldings'; and Camdon, probably a Lumière man, in 'Varyete Theatre' - all places with western names. In addition, publicity was printed in French, German, Armenıan and Greek but not in Turkısh. Pera was posed as an object of desire for the Muslim upper class and, partly, for the intellegentsia at a tıme of modernızation fuelled by western-onented policies, and the cinema seems to have served as the latest desiring machine - the films that were shown presented glamorous scenes from various European centres, and filmgoing itself had the charm of being a western-style ritual $^{3}$

Murebbiye is not the only example of a national cinema that produces a discourse of resistance while a general perception of cinema itself was already constructed entirely in western terms And it is not surprising that, as far as national cinemas are concerned, any formulation of resistance is overshadowed by images of mimicry. Turkısh popular cinema, Yeşılçam, whose death was announced in the early 1980s, had been frequently critıcized for imitatıng other cınemas, and repeatıng other films. ${ }^{4}$ Back in 1968, the film magazine Yenı Sinema (New Cinema) noted that more than half of the 250 films made that year were adaptations - plagıarısms, to be more precise - of foreign box-office successes. ${ }^{5}$ Given this fact, one can easily deduce an identity crisis, but what are we to make of an identity which is in permanent crisis? And what kind of national identity can be formed from a conema renowned for its fallures rather than its successes, or for its endless efforts to mimic others rather than to produce films that are 'Turkish to the core'?

In this essay I will examine the dynamics by which Turkish popular cinema describes a national identity, and I will attempt to demonstrate how the specificity of this identity can be seen in the very way it mimics and resists others Cinema, as a desiring machıne, produces a discourse which operates on a social level, involving psychical processes with subject effects. I will argue that these psychical processes are characterized by ambivalence (for example, mimicry and resistance) which provides a ground for the 'identity in crisis' I refer to above In this respect, I will make use of postcolonial theory, particularly its formulation of the ambivalent nature of colonial discourse and the way it operates on the social unconscious. However, I am not going to offer an analysis of 
6 I borrow this expression from the title of a book by Partha Chaterjee Nationaltst Thought and Colonal World a Derwative Discourse /Minneapolis University of Minnesota Press 1993)

7 Daytıme women only screenings were part of a strategy developed by the move theatres to regulate this demand
8 Ayse Sasa Yeşılçam Gunluğu (Istanbul Dergah, 1993) p 30 colonial discourse as such, rather I will focus on 'the discourse of the national identity as derivative of colonial discourse' as articulated by Yeşılçam ${ }^{6}$ Indeed, Turkısh popular cınema is one popular sıte where such an 'identity in crisis' has been experienced for decades

My study covers the period when commercial cinema enjoyed its heyday - that 1 , between the mid 1960s and mid 1970s - producing an average of two hundred films per year Konfeksivon films, as they were called, were made in a rush to meet a contınuously increasing demand.' Not only did they entertain the domestic audience, they also became very popular in other Middle Eastern countries, such as Iran, Iraq and Egypt. Production declıned dramatically after the 1980 s, and today only about ten Turkish films reach the movie theatres each year. This is primarly due to the US film distribution companies that now control exhibition mechanisms in Turkey, and secondly to the gap between the audience and the inaccessible discourse of current Turkısh films, many of which follow the conventions of European art cınema. The new Turkish cinema has lost its audience to television channels which repeatedly show old popular films - the frequency of commercial breaks suggests that these films stıll appeal to a mass audience, stıll contribute to popular imagery.

\section{Turkish popular cinema: a field of tensions}

The first three decades of Turkish cinema were marked by the domınatıon of a single man, Muhsın Ertuğrul, who was, and is stıll, widely criticized for transferring the stylistic devices of theatre to cinema. This period came to an end in 1953, when a number of filmmakers inıtıated a somewhat different practıce Ayşe Şasa, a veteran scriptwriter, calls this the period of the 'illiterates', in that they were netther aware of, nor interested in, the artistic possibilities of the cinema. Craftsmen of rural and lumpen origin now ruled Yeşılçam. They dıd not hıde theır commercıal interest in the films from which they made big profits. Sasa maintains that the period of the 'illıterates' in Turkısh cınema was undervalued because of its low-quality films: its potentıal of growing a genuine conematıc 'seed' was underestımated, as was 'the poetry that was hidden in this artless authenticity'.

The mid 1960s witnessed the beginning of a debate about national identity in Turkısh cınema. A group of writers from various branches of literature gathered around the film magazıne Yeni Sinema, and founded the Turkısh cınematheque (with some help from Henrı Langlois) They argued that a national cinema with international concerns was ımpossıble withın Yeşılçam, whıch was associated with worn-out formulas, plagiarısm, escapısm and exploitation. While Yent Sinema published interviews with film directors such as Godard, 
9 Ece Ayhan, a famous poet evaluated the contributors to a short film competition 'This Young Generation of honour has chosen to work away from Yeşlçam in order not to fall prey to tt Simurg Yen Sinema nos 19/20 (June/July 1968), p 10

10 Halıt Refiog Ulusal Sinema Kavgası (Istanbul Hareket, 1971). p 47

11 We refuse to collaborate with the Turkısh cinematheque and its pubication Yeni Sinema for their hostility to the Turkısh cinema in general and Turkssh filmmakers in particular Memouh Un, Atıf Yilmaz Metin Erksan Lutfi Akad Duygu Sagroglu Alp Zekı Heper Osman Seden Halı Refiğ Yent Sinema no 4 (July 1967) p 34
Renoir and Antonıoni, and translations from theoretical works examınıng cinema in relation to other arts, screenings organızed by the cinematheque gave a particular audience access to canons of European art cinema. When one looks back at this scene, one can see a programme aimıng at an art cinema. If, in Europe, art cinema developed as a resistance to the increasing domination of Hollywood, In Turkey, Yeşılçam appeared as the first obstacle to be tackled; alternatıve modes of production were sought, and festivals and competitions held to promote short films. ${ }^{9}$

When the Aslatic mode of production championed by the novelist Kemal Tahır became a popular issue in the late 1960s, a close frend of his, the then film critıc and promısıng film director Halit Refiğ, elaborated a concept of national cinema. films are made by money coming from the people, so they must be made for the people, one way or another. Since it is impossible to reach the people of Turkey via western forms, a cinema which considers the people's characterıstıcs and needs must be developed withın Yeşılçam, whıch already has formed its audience. Refĭg insısted that Yeşılçam relıed less on a capitalıst mode of production than on a labour-intensive one, and urged film writers and producers not to turn their backs on it. He used ironic language when he criticized the elitist approach of the cinematheque group:

To sum up, cinema [according to the group of cinematheque] is a universal art. The criteria for the evaluation of this art are provided by the West. To be able to make a good film, one must do whatever a western filmmaker would do. There is no point in takıng an interest in Turkısh films as they do not subscribe to western criteria .. and one must fight to have the Turkısh audience develop a sympathy for and to love films coming from the West. ${ }^{10}$

In 1967 the major film directors of the time refused to respond to a questionnaire on the role of criticism prepared by Yeni Sinema, and that was the end of relations between filmmakers and the cinematheque " Here is a list of keywords which represent the two cinemas (one of which was only a programme then)

New Cinema
western
art cinema
model. European art cınema
to create
auteur policy
alternative modes of productıon
festivals, competitıons

\section{Yeşilçam}

domestic popular cınema model: Hollywood to produce star system capitalıst mode of production production-distribution-exhibition

Inevitably, the sharp conflict in this set of oppositions was occasionally resolved by some directors. Yilmaz Guney, for instance, 
12 John Gillet Sight and Sound vol 2 no 4 (1992), p 5

13 Thomas Elsaesses Primary identification and the historical subject Fassbinder and Germany Cine.Tracts vol 3 no 3 (1982) p 52 produced popular, commercially successful films which were also halled by the conematheque group At the beginning of the 1980s, New Cinema began to introduce its first films to the domestic audience (and to international film circles), but it could not get out of the domain of Yeşılçam entırely. At first Yen Sinema attempted to win over some establıshed directors, Lutfi Akad and Yilmaz Guney among them Then came a generation of young filmmakers who tned hard to differentiate their films from those of popular cinema although they made these films in Yeşılçam, they sought recognition from international art cinema institutions In Yeşılçam, stars were used to brand the film product, the New Cinema directors also worked with stars but, following auteur policy, the director was inscribed as the 'creator' of the film. Audiences began to read authorial credits, such as 'an Alı Ozgenturk film', 'an Omer Kavur film' In additıon, the New Cinema assumed the point of view of European art cinema (which includes the European audience) in that it produced representations of Turkey etther as an 'impenetrable other' (Hazal, Bedrana, Kuma/The Concubine) or as a fantasmatic western country (Piano Plano BacaksizIPiano Plano My Little Boy, Sen Seviyorum Rosa/l Love You Rosa, Yengeç Sepeti/The Crab Basket, Gizlt Yuz/The Secret Face). It is interesting to note that a Britush film critic, reporting from an Istanbul Film Festival in 1992, describes the latter films as 'pretentıous allegories drawing on influences from Buñuel to Bergman'.12

The mid 1970s witnessed television and sociopolitical catastrophe pushıng Yeşılçam ınto another crısıs, whıle New Cınema contınued to seek its audience by way of international festivals and other such events. Thomas Elsaesser makes a simılar observation about German cinema in the early 1980s:

the Germans are beginning to love their own cinema because it has been endorsed, confirmed and benevolently looked at by someone else: for the German cinema to exist, it first had to be seen by non-Germans. It enacts, as a national cınema now in explicitly economic and cultural terms, yet another form of selfestranged exhıbitionism ${ }^{13}$

To echo Elsaesser in a slıghtly different context, for Turkısh art cinema to exist, it had to be "endorsed, confirmed and benevolently looked at' by some one else. But unlıke German cinema, with a few exceptions it never enjoyed such recognition. What was expected from German cinema was, for instance, the sophistıcated, selfreflexive films of Fassbinder This has not been the case for Turkısh cınema. Susuz Yaz/The Dry Summer (Metın Erksan) and Yol (Yilmaz Guney), which won prizes at major festivals, both illustrate the harsh circumstances of rural life stricken with poverty, absurd moral values, oppressed individuals, and so on Roy Armes's comment on 
14 Roy Armes Twelve propositions on the inaccessibility of thiro world cınema in Christıne Woodhead led) Turkish Cinema an Introduction lLondon Turkish Area Siudy Group Publications 1989) $\rho 7$
15 Slavo Žizek The Sublime Object of ideology (New York and London Verso 1989) pp 32-3
16 Thomas Elsaesser Tales of sound and fury observations on the farnily melodrama in Bill Nichols (ed) Moves and Methods Volume II lLondon University of Calıforna Press 1985) p 177

17 Steve Neale Melodrama and tears Screen vol 27 no 6 (1986) $\rho 6$ the relationship between the Third-World cinema and intelligentsıa is relevant here.

But the processes of their education and the advent of national independence will have made them very aware that they cannot become western filmmakers. Hence they will tend to prove their identity by plunging deeply into local tradition, myth and folklore. The result is all too often an ambiguous cinema which is too complex in form for local audiences and too esoteric in substance for western spectators. ${ }^{14}$

That 'they cannot become western filmmakers' needs further elaboration. I want to demonstrate that fetıshism and, relatedly, fantasy complicate things further Indeed, Turkısh film directors are very well aware that they cannot become western filmmakers, but the fetıshistic disavowal of difference keeps them moving in the same direction (to adapt the famous 'I know very well but nevertheless ', 'I am very well aware that I cannot become a western film maker, but nevertheless ..') The problem is not in knowıng but in doıng, as Slavoj Žıžek maintaıns.

They know very well how things really are, but stıll they are doing it as if they did not know. The illusion is therefore double. it consists in overlookıng the illusion which is structuring our real, effective relationship to reality And this overlooked, unconscious Illusion is what may be called the ideological fantasy. ${ }^{15}$

Turkısh art cınema deserves a more detaıled analysis, but I want now to return to Yeşılçam and to demonstrate that the dıssemınatıon of colonial discourse is not exclusive to New Cinema I will concentrate upon melodrama as a popular genre which plays on desire, providing us with invaluable insight into the ambivalent nature of national identıty.

\section{The identities of melodrama}

As Thomas Elsaesser observes, famıly melodrama,

dealıng largely with the same Oedıpal themes of emotional and moral identity, more often records the fallure of the protagonist to act in a way that could shape the events and influence the emotional environment, let alone change the stifling social milieu The world is closed, and the characters are acted upon, and each other's sole referent, there is no world outside to be acted on, no reality that could be defined or assumed unambiguously ${ }^{16}$

Steve Neale notes that 'melodramas are marked by chance happenıngs, coincidences, missed meetıngs, sudden conversions, last mınute rescues and revelations, deus ex machina endıngs'." 
18 Elsaesser, Tales of sound and fury p 168

19 At this point Yeşlç̧am gets closer to Indian melodrama Ravi Vasudevan gives an instance of a fernale character who was sentenced to death for murdering a man but thınks she is already guilty of having adopted customs alien to their land /Andaz/A Sense of Proportion [Mehboob Khan 1549l) The melodramatic mode and the commercial $\mathrm{H} i n d ı$ cinema notes on film history narrative and pesformance in the 1950s Screen vol 30, no 3 (1989) pp 41-4

20 Mehmet Açar notes that the innocent gurl is always offered a western drınk often whısky when she is to be seduced felakete çeyrek kala Sinema (February 1996) p 88

21 I thank Mahmut Mutman fo drawing my attention to this issue
Melodrama, in short, is perfectly suıted to Yeşılçam, whıch stıcks to narrative traditions inspired by legends, fairy tales and epopees (rather than by, say, tragedy, which emphasizes the inner conflicts and transformations of its characters). While, in its beginnings, western melodrama recorded the 'struggle of a morally and emotionally emancipated bourgeors consciousness against the remnants of feudalısm', ${ }^{8}$ Yeşılçam exploits melodrama in artıculatıng the desires aroused not only by class conflict but also by rural/urban and eastern/westem oppositions. Immigration from rural areas to big cities is still a social phenomenon with significant economic and cultural consequences. The possibilities of crossing from one class to another and from village to big city provide the ground upon which melodrama plays and activates its machinery of desire. Hence the formulation lower class/rural = East/local culture vs upper class/urban $=$ West/forelgn culture.

The Yeşılçam melodrama repeatedly returns to the 'boy meets gırl' plot. they unite, they split, they reunite. In one particular variation, the boy from the urban upper class and the girl from the lower class have an affair and then the boy leaves the girl. The girl finds hım again, but learns that he no longer wants her She comes back in disguise (urban, rich, sophisticated) and the boy, having failed to recognize her, falls in love. This time the girl takes her revenge and leaves him In the end, her identity is revealed and the boy learns his lesson. The upper class, which is fixed as the object of desire here, is encoded with its western attributes. ${ }^{19}$ Luxurious Amencan cars, blondes wearıng revealıng dresses, crazy parties and whisky all connote moral corruption, and construct an conography of the West. ${ }^{20}$ This is in sharp contrast with the virtues (sımplicity, loyalty, correctness and chastity) of the woman from the rural area/lower class. In a recurrent plot, the herome is raped/seduced and immediately deserted by a man whom she already loves. She has a baby and brings it up under reduced circumstances, and then somehow becomes rich. Towards the finale, having come to appreciate the herome's virtues, the long-lost lover, now father, returns, but the heroine's pride delays the reunion (Sana Donmeveceğım/I Will Never Return To You, Aysem/Ayşe Mine, Kmalt Yapincak/Golden Red Grape). In Dağdan Inme/Came Down From The Mountains the male hero is struck by the appearance of an extremely attractive woman he meets at a party She is actually a villager, desperately in love with hım. Taşra Klzl/The Girl From The Province tells the story of a girl who comes to Istanbul from a small town. She moves into the house of an old family friend, who turns out to be her father Thıs film, like many others, exemplifies how melodrama resolves conflict using the Father figure (as father, police chief, judge, boss) as its agent. ${ }^{21}$ In many instances the authoritarian Father plays the benefactor, and sides with the girl against the spolled son There are, of course, some contradictory variations (for 
example, the rich father making friends with two young men who turn out to be his daughters' boyfriends). Vanations, however, do not negate the argument that the Father regulates the cconomy of desire and power. The message, which is of course addressed to the lowerclass/rural subject, is that the upper class will be able to survive only if the lower class helps Possibılities of identıfication in these films are a matter of justifying the audience's (especially female audience's) desire for, and wish to be desired by, the upper class Yeşılçam melodramas thus offered a sense of legıtimacy to the squatters who had migrated from rural areas.

Plagiarısm, of whıch Yeşılçam has often been accused, is by no means a simple issue. The technıcal and stylıstıc devices of Yeşılçam differ radically from those of Hollywood and European cinema.

Lıghtıng, colour, dubbing, dialogue, shootıng practıces, point-of-view shots and editing create a very specific cinematic discourse in even the most faithful of adaptations. In trying to meet a demand for two hundred films a year, production practices had to run at great speed and thus by default a visual tradition of shadowplays, miniatures, and so on was revived To save time and money, shot/reverse-shot and other point-of-view shots were avoided as much as possible. This meant the domination of front shots. characters mostly performed facıng the camera and did not turn their backs to it. This made full identıfication impossible and gave way to empathy instead. When a Hollywood film shows a box, it says 'Thıs is a box' Yeşılçam, on the other hand, attempted to achieve the same statement but could not help saying 'This is supposed to be a box, but actually it is only an image which represents a box' Yeşılçam was a hybrid cınema it produced a cınematıc discourse blendıng Hollywood-style realısm with an unintentional Brechtian alienation effect

Characters who were never depicted as individuals, and who could not act but were 'acted upon', reınforced the melodramatic effect Given such circumstances, it is not difficult to see why split identities have always been convincing for, and appealıng to, the audience. The Yeşılçam character can trıck her lover ınto belıeving that she is someone else, taking on various successive identities What was once a poor, uneducated girl with a strong accent can instantly become an attractive, sophisticated lady of manners. A girl from the lower class can adapt herself to the rules of the high society she has just joined without any trouble These are, of course, narrative reproductions of Pygmalıon and Cinderella. If we can hazard that splittıngs are mobilized by presenting the upper class/West to the lower class/East as an object of desire and ıdentification, then splıttıng is a symptom whıch betrays Yeşılçam's own conception of national identity Ambivalence (narcissısm/ aggression), identification and fantasy are the basic terms of the logic of this conception. Splitting, as a matter of fact, provides the ground for ambivalent psychical positionings of the subject in relation to its 
object of desire, and transition from one identity to another takes place in the realm of fantasy after the poor young girl is discovered by the owner of a night club, she quickly becomes a rich and famous singer The huge efforts required to achieve success (private education from a non-Muslim instructor, music lessons, traınıng, rehearsals) are either shown in a rapid succession of scenes or ignored entırely.

\section{Apollo, molotov cocktail and 'The Favourite of Maharajah'}

Now I want to examine a film which, I believe, focuses the problem of national identity as denvative of colonial discourse

Karagozlum/My Dark Eyed One (Atıf Yilmaz, 1970) is not a typical or normal melodrama; even its plot is different from the ones I have so far described Rather it is a limit-text, which stands at the margins of the logic of melodrama, and this is why $I$ thınk it is capable of representıng Yeşılçam melodrama perfectly.

Azıze (Turkan Şoray) is a fisherman's daughter who enjoys singing while she works in the fish market. She happens to meet Kenan (Kadır Inanır), an ıdealıst composer who disdaıns all kınds of music but western classical. Teasing hım for his pretentious cultural preference she names him 'Chopın' As in the case of many melodramas, Azize is then discovered by the owner of a music-hall, and becomes a famous singer, findıng herself in an entırely different network of sociocultural and economic relations Kenan, having falled to find a decent job, begins work as a watter at the same place. They eventually fall in love Kenan drops classical music in favour of composing popular songs for Azıze ('I retıre from Chopınhood'). He mails his work anonymously to her, never revealıng his identity. Two Hollywood producers who happen to hear her singing one night offer to co-star Azize with Rock Hudson in a film ('The Favourite of Maharajah') on the conditıon that she will bring her 'unknown composer' along with her to Hollywood She is delighted with the idea that she will enjoy world-wide fame, but her mysterious, hitherto unknown composer (Kenan disguised as an old man) shows up, and not only declines the offer but also accuses her of 'being adrift in a Hollywood dream' He deserts Azıze and gets engaged to Semra, the daughter of a rıch famıly Azıze, havıng discovered that 'one who wants to have everything, loses what she already has', quits her job and goes back to sellıng fish. But, in the end, Kenan reappears and they are reunited.

The film is very quick to establish the opposition of East/popular culture and West/elite culture. In the scene following the opening, Kenan's close friend, Orhan, advıses hım to drop 'thıs kefere [ınfidel's] music which is a pain in the neck' and perform his art for a larger audience in order to make a fortune from his talent. Once 


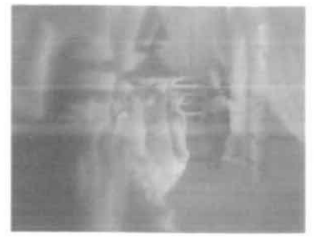

Fig. 1. Korgoazlinaswy Oark Erod ons (Adit Yilmaz, 1970).

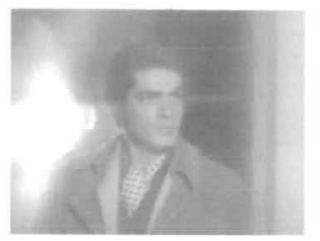

Fig. 2.

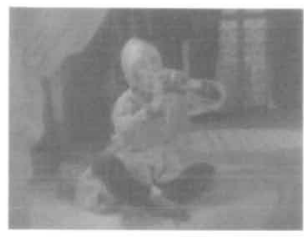

Fig. 3.

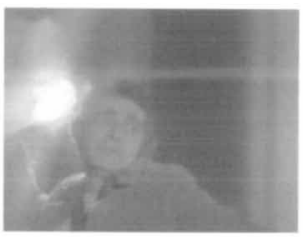

Fig. 4.

2. Mahmul Mutman. Pictures from afar: shooting the middle east' Inscriptions, no 6 (1992). p. 15
Azize starts working at the music-hall she cannot enjoy the new life she is expected to lead. When the vacuum cleaner goes dead in a power cut, she and her assistant happily use brooms. They are almost embarrassed to use mechanical appliances for any kind of housework that can be done manually. Technology not only marks a class conflict here, it also serves as an icon for a western lifestyle.

But the dream sequence is most significant since it reveals the 'intention of the text'. In order to go to Hollywood Azize has to locate her unknown composer, but Kenan is none too happy with her enthusiasm, and is reluctant to give away his secret. As he tries to make his mind up he falls asleep and has a dream. In the dream we see the chamber of the maharajah. Azize enters the scene and begins to dance in front of a man whom we are not allowed to see (fig. 1). Then Kenan sneaks into the chamber through the back door, and becomes furious when he sees Azize dancing for someone else (fig. 2). In response, Azize puts out her tongue in mockery. But what strikes Kenan most is that right behind Azize, accompanying her on the flute, he sees himself, dressed in Indian clothes (fig. 3). Kenan produces a bomb (a molotov cocktail) from the pocket of his coat and throws it right into the middle of the chamber (fig. 4). The bomb explodes and Kenan awakes. He has made his decision: he will not let Azize go to Hollywood.

When Kenan detonates the bomb we do not see any damage done: we do not see the palace falling into pieces, we do not see anybody killed, and we do not hear any screams. We see only a smoke-screen and then, in closeup, Kenan awakening in dismay. What has broken down is not the content of the dream but the fantasy screen itself.

As Mahmut Mutman stresses, colonial discourse and orientalism play on sexual difference. Psychic processes (fantasy, castration, fetishism, aggression) which mobilize the discourse, enable the re-presentation of Woman as a cultural construct: 'Muslim woman stands where the political, the economic and the cultural "values" meet: her culturally specific embodiment is the commodity that is exchanged with other commodities' ${ }^{2}$ Which applies to both sides (colonized and colonizer) of colonial discourse. In Turkish, anavatan and anayurt, which might be translated as 'motherland' and 'mother country', are terms which explain how Woman comes to represent values attached to the concept of nationhood. And this is precisely what Karagözlüm does through the agency of Kenan: Chopin/the unknown composer is asked to trade Azize for a brilliant career (she dances to his music). Azize, an Arabic word in origin, means 'dear' or 'beloved' in Turkish and can easily be associated with the common usage Aziz Vatan (beloved country). The molotov cocktail was an icon of the militant Left in the 1970s, frequently used in demonstrations against the growing US hegemony. It was considered an unsophisticated, cheap, easy-to-produce, easy-to-use combat weapon, a suitable device for a 'people at war with imperialism'. 
What seems problematic to my analysis at this point is that Kenan's dream actually serves as a screen onto which 'Hollywood' projects its fantasy. It is also the very dream Kenan refers to when he accuses Azize of being adrift in a Hollywood dream

Through his music, Kenan fixes his beloved as an object of desire, and then exhibits her body (that is, hands her over) to Hollywood. More importantly, the splittings of Kenan verıfy the ambivalence of colonial discourse there is a Kenan (the flute player) who accompanies Azıze with his music, a Kenan (the white male hero) who is struck by what is going on in the scene and explodes the bomb, and finally a Kenan who dreams all of this. I suggest that the dream sequence forms the kernel of the entıre film. The splittıngs that take place within it are parallel to the diegetic ones: the flute player is the unknown composer, now unmasked, the one who bombs the palace is the waiter, and the one who dreams is a Kenan who retıred from 'Chopinhood' in favour of Azize. But who is the maharajah? Although we see very little of hım, he is a pivotal figure around which the rest of the characters revolve. Motionless, he is watching Azize dancing It seems he controls the space with his gaze. He can see Azıze and the flute player and vice versa. He cannot see the waiter (or the audience), and although the waiter cannot see his face he is very well aware of his presence. So the maharajah is also a borderline separating the watter and the audience from Azıze and the flute player. The audience identıfies first with the dreaming Kenan and then with the watter. When Kenan throws the bomb, he not only puts an end to the dream, but also to the voyeuristic pleasure of the maharajah. The audience of the exotic films of Hollywood shares the erotic experiences of the Oriental despot and then identifies with the white male hero who bursts into the palace and takes the girl away from him. In this connection, the explosion has a double effect which brings us back to the problem of split identities: Kenan tears apart the fantasy screen of 'Hollywood', yet identifies with it by playing the white male hero who is already a part of this same fantasy. Therefore, Karagozlum offers us a dual set of relationships which reveal the actual fantasy of the colonized - to share the colonizer's fantasy. This is made possible by a subtle reversal the narrative switches positions and the colonized becomes someone other than Kenan. Aggression takes place elsewhere, neither the word 'maharajah' nor the settıng is Turkısh, but it is stıll Oriental.

Azıze and her father ride to the fish market on a shabby motorcycle they have named Apollo. If we go back to 1970, the production date of this film, we can see the reference to the US moon landing. To name an old motorcycle after Apollo is a parody intended as mockery, but as Fredric Jameson emphasizes in a different context, 'the parodist has to have some secret sympathy for the original' and 'there remains somewhere behind all parody the 
23 Fredric Jameson 'Postmodernism and consumer society in $\mathrm{Hal}$ Foster (ed) Anti aesthetic Essays on Postmodern Culture (Port Townsend Bay Press 1986). pp 113-14

24 It must be noted that Karagözlüm borrows its itte from a popular song like many other Turkish films feeling that there is a ... norm'. ${ }^{23}$ And Karagozlum re-establishes western norms by illustrating cultural deviations Throughout the film we hear three sorts of music, representing three levels of culture: classical western music (Kenan - the norm), traditional Turkısh popular musıc (Azıze - the settlement) and popular dance music (Semra - the corrupt) ${ }^{24}$ Kenan has to sacrifice classical music (the norm) for Azıze and the values she represents (the popular), when he thınks he has lost her to Hollywood, he decides to marry Semra (the corrupt).

My observation is supported by another film. In Sana Tapivorum/I Worshıp You (Aram Gulyuz, 1970), Ayşe (Zeynep Değımencıoğlu) studies ballet at a dance school. In order to meet her expenses, her mother works as a singer in a night club, which utterly embarrasses Ayşe When the rumour is spread that her mother is more or less a prostitute, Ayşe is cut by her classmates and teachers. She drops out of school under pressure and, at the same time, she is informed that her mother is dangerously 111 . The doctors tell her that she will die unless she is sent to Switzerland for an operatıon. Ayşe is desperate because she cannot afford to pay for the operation Her mother's boss offers her money, but she would have to dance in his night club in return. When Ayşe refuses the offer furiously, he asks ironıcally whether her body is more sacred than her mother's life, remarkıng that her mother did the same thing in order to be able to pay her tuition fees, upon which Ayşe agrees to start workıng in the night club. Ayşe's classmates and teachers appreciate the sacrifice she has made for her mother and decide to help her. In the meantıme, Ayşe locates her long-lost father, who was once a famous brain surgeon and is now an alcoholic, and after a climactic speech she persuades hım to do the operatıon. In the final scene we see Ayşe takıng the leading role in a ballet performance and all the characters in the audience, especially the owner of the night club regretfully weepıng. Her body, as in many Yeşılçam melodramas, is a metaphor for postponement and sacrifice. Once agan, Woman provides the ground for an exchange of values. The body which represents the cultural values of the dance school (the norm) is not more sacred than the Mother. It must be sacrificed for the Mother and submitted to the night club. Only then will the Mother survive and the Father assume his identity.

\section{'Pay it to the waiter!'}

As I have tried to demonstrate, colonial discourse and its denvatives operate in a vast area, and netther nationalısm nor any other sort of antı-western practice can easıly avoid reproducıng them For Yeşılçam, the moment of colonıal discourse is the moment of transgressing the boundarıes it has defined. Yeşılçam depıcts the 
West perjoratıvely; however, it supresses the fact that the social class which represents the West is represented in fantasmatic scenes where everything can be vindicated and thus desıred unashamedly.

One must, nevertheless, not forget that Yeşılçam melodrama stages a real ambivalence in the sense that reversals work both ways. It imposes the cultural values attached to national identity as necessary and temporary deviations. One must conform to them for now so as to acquire the norm (that is the West) in the future. To be able to be Chopin one day, one must be a watter or an unknown composer now - because Azize is at stake; to be able to go back to the dance school one day, one must work in a night club - because mother is III and money is required for the operation.

When the Hollywood producers burst into Azıze's dressing room to meet her, the owner of the music-hall cannot figure out what they want. 'They want the bill', Azize guesses, and points to Kenan, who happens to be there. 'Pay it to the waiter', she suggests Kenan's intervention prevents Azıze from going to Hollywood, so Hollywood does pay the bıll to Yeşılçam ın a way. Yeşılçam seems determıned to demand a payment, only it cannot avoid reproducing colonial discourse once again, since it fixes national identity precisely in thıs problematic moment.

An earlier version of this essay was presented at the Theory Culture and Society Conference Berlin August 1995 I wish to thank Mahmut Mutman and Stephanie Donald for theır comments 